\title{
6 \\ Control or manipulation? Nuclear power in Taiwan
}

\author{
Gloria Kuang-Jung Hsu
}

\section{Abstract}

Over the last three decades, the development of nuclear energy in Taiwan has shifted from a secret weapons program to civilian applications, from an expansion of nuclear power towards a nuclear-free future. But some countries may still wish to gain weapon capabilities through civil programs, as Taiwan did many years ago. Even though the days of military involvement have long gone, the past still casts a long shadow over those in the field of nuclear energy. An old nuclear culture persists, and advocating nuclear power is still more important than safety regulation. Unless nuclear safety can be restored to its rightful position, continuing current practices are likely to threaten operational safety and risks, placing waste management in disarray. Over the years, a number of nuclear-related incidents have occurred in Taiwan, demonstrating the importance of having a system of checks and balances, strictly enforced through domestic and international transparency.

\section{Introduction}

Taiwan's Chin San nuclear power plant's Unit-1 has been idle since December 2014, pending legislative hearings on the broken handle of a fuel assembly. Of six operating nuclear reactors in Taiwan, four have full spent fuel pools, with no space for a full core removal in an emergency. 
The reactors are nonetheless allowed to continue to operate. Interim spent fuel dry storage programs, which have been criticised for their lack of basic safety features, have been put on hold by the local government.

On 20 May 2016, Ms Tsai Ing-Wen of the Democratic Progressive Party (DPP) was inaugurated as the president of Taiwan. Before the presidential election, Tsai promised that Taiwan would become nuclear free by 2025 . Two days after Tsai won the election in January 2016, the Taiwan Power Company (Taipower) swiftly updated its projection on future power shortages from high risk to little risk if Taiwan becomes nuclear free (Lin 2016a). Two months later, Taipower chair Huang Chong-Chiou denied that Taipower had ever made any such U-turn in its electricity projection, and said he could not guarantee adequate electricity supply without nuclear power (Huang 2016). Taipower's apparently contradictory statements were criticised at the time as a political reflex, devoid of professional judgement.

As if trying to prove Huang's point, in May 2016, Taipower began issuing warnings of a possible power shortage (Lin 2016b). Seemingly manipulated by Taipower, Premier Lin Chuan announced his intention to restart troublesome Unit-1 of the Chin San nuclear power plant to fill the electricity gap, only two weeks after Tsai's inauguration. Lin's remarks immediately provoked vehement criticism from civil society and from DPP legislators who were outraged by this betrayal of President Tsai's nuclear-free promise. Premier Lin retracted his words the next day.

This incident exposes the administration's limited understanding of the intricate relationship between Taipower and the Atomic Energy Council (AEC), and their role in Taiwan's energy policy over the last four decades. Unless the government is willing to seek advice from outside the establishment, many risky and urgent nuclear-related problems will remain unresolved. 'Nuclear free' will remain only a slogan.

In this chapter, I describe the early secret nuclear weapons program in order to help understand the power distribution and the psychology behind the scenes. Next, I describe the devolution to peaceful applications, the emerging significance of Taipower, the fourth (Lungmen) nuclear power plant controversy and its current status, and future challenges. I then outline nuclear waste problems, the discovery of numerous radioactive buildings, the low-level waste storage facilities on Orchid Island, and recent spent fuel reprocessing issues. In the final section, I discuss reasons for a series of unfortunate incidents, and why new Taiwanese policymakers should try hard to prevent history from repeating itself. 


\section{Taiwan's early nuclear weapons program}

\section{The Israeli connection and US opposition}

The story begins with an arms race between the ruling Kuomintang (KMT, Nationalist Party) and the People's Republic of China. In March 1962, President Chiang Kai-Shek learned from US intelligence that China was developing a nuclear weapons program in northwest China. Not wishing to fall behind the Communists, Chiang decided to pursue a nuclear weapons program. Dr Ernst Bergmann, Chair of the Israeli Atomic Energy Commission, in response to an invitation by General Tang Chun-Po, paid a secret visit to Taiwan in 1963 and spent three days at Sun Moon Lake Resort with President Chiang and General Tang (Wang 2010).

In spring 1964, the establishment of the military-controlled Chung Shan Science Institute (CSSI) for nuclear energy, rocket propulsion, and electronics was formally announced. General Tang served as chair of its preparatory bureau and Dr Bergmann as its foreign advisor. To facilitate the nuclear weapons program, the Defense Ministry immediately started sending talented military personnel overseas for advanced science and technology degrees.

In October 1964, China successfully detonated its first atomic bomb. Taiwan's nuclear weapons program, the Hsin Chu project, was initiated with Bergmann's assistance, and included a heavy-water reactor, a heavywater plant, and a reprocessing plant. The CSSI began its work in July 1969; it had three research departments, including the Institute of Nuclear Energy Research (INER). President Chiang nominated the renowned physicist Wu Da-You as chair of the National Science Council in 1967, hoping for his assistance on the nuclear weapons program. Instead, Dr Wu submitted a 10,000-word written statement forcefully repudiating the idea. In the meantime, Western intelligence started to suspect that something underhand was afoot. The Israeli newspaper Haaretz first reported visits of atomic scientists from Taiwan in December 1965. ${ }^{1}$ It was learned later that Dr Bergmann was their contact person.

1 US Embassy Tel Aviv, Nationalist Chinese atomic experts visit Israel. Airgram 793, 19 March 1966, in Burr (1999). 
In early 1966, the Taiwanese government approached West Germany for a 50 megawatt (MW) heavy-water reactor from Siemens. As this was the first major German nuclear equipment export, the German government favoured the deal, on the condition that sensitive parts would be secured under International Atomic Energy Agency (IAEA) safeguards. Taiwanese officials stated that the reactor would aid research for an economic feasibility study and would be operated by the Union Industrial Research Institute of the Ministry of Economic Affairs, instead of the state-owned Taipower. ${ }^{2}$ Taiwan's representatives repeatedly claimed that there was no relationship between the reactor purchase and nuclear weapons research. The United States remained unconvinced and strongly opposed the sale of the German reactor to Taiwan.

Also in 1966, four experts from the IAEA travelled to Taiwan to help with site selection for two $450 \mathrm{MW}$ nuclear power plants, one in the north and one in the south of the island. During the site selection process, a Taipower representative requested an additional site for a $200 \mathrm{MW}$ reactor, as a pilot plant, in either Hsin Chu or near Shimen Dam. The Taipower representative said that this $200 \mathrm{MW}$ reactor would be sponsored by a 'consortium' of universities and other government institutes. The US Embassy immediately suspected military involvement. ${ }^{3}$ Archival evidence from electronic briefings to the US Embassy in Taipei confirms that Taiwan intended to proceed with nuclear weapons development. ${ }^{4}$

The Hsin Chu program was aborted in 1969, probably due to a combination of domestic and international pressure (Albright and Gay 1998). Dr Wu strongly opposed the weapons program for being too costly and too close to the population centre. The Taiwanese authorities also worried that the international community could deny Taiwan access to all nuclear resources and that a direct confrontation with the United States was possible.

2 US Embassy Taipei, GRC plans for purchase of 50 megawatt (MW) heavy-water nuclear power plant. Airgram 566, 30 April 1966, in Burr (1999).

3 US Embassy Taipei, GRC request to IAEA team for advice on location of reactor for possible use by military research institute. Airgram 813, 8 April 1966, in Burr (1999).

4 US Embassy Taipei, Indications GRC continues to pursue atomic weaponry. Airgram 1037, 20 June 1966, in Burr (1999). 


\section{A deceptive shift of focus}

After terminating the Hsin Chu program, Bergmann persuaded President Chiang to modify Taiwan's nuclear strategy by considering civilian applications of nuclear power. To dilute its ability to function militarily, the INER was reassigned, from the military-controlled CSSI to a new position affiliated with the AEC, as proposed by Dr Wu. The president of National Taiwan University was named as head of the CSSI. Soon after, genuine civilian programs were initiated. The Executive Yuan approved the first nuclear power plant project in August 1969. Two General Electric (GE) light-water reactors (LWRs) were acquired in 1970. Two more boiling water reactors were considered for purchase in 1974. These civilian nuclear activities persuaded some United States intelligence officers that Taiwan had shifted its focus: 'This type of reactor is not by any means an optimum choice with regard to producing plutonium for weapons use', a US Embassy official noted. ${ }^{5}$

Meanwhile, Taiwan launched another secret nuclear program codenamed 'Tao Yuan'. But Taiwan's attempt to purchase a reprocessing facility from the United States was vetoed by the Richard Nixon administration in 1969. Instead, the INER acquired a $40 \mathrm{MW}$ heavy-water reactor from Canada, which became critical in April 1973. Combining equipment acquired from the United States, France, Germany, and other countries, the Taiwanese developed a small reprocessing facility, a plutonium chemistry laboratory, and a plant to produce natural uranium fuel (Albright and Gay 1998). The plan to purchase a reprocessing plant from France failed due to an exorbitantly high price and/or pressure from Beijing. ${ }^{6}$ Washington learned that the Taiwanese government had turned to a West German firm for parts for a reprocessing plant in 1972. But it being a time when the Sino-US relationship was normalising, and not wanting to agitate either Taiwan or China, the US did nothing.

Washington, nevertheless, steadily increased pressure on Taiwan to forego its nuclear military program. The United States offered to support Taiwan's reprocessing of spent fuel in the US or other countries so that the

5 US Embassy Taipei, ROC nuclear intentions. Cable to State Department No. 2354, 20 April 1973, in Burr (1999).

6 US State Department, German inquiry regarding safeguards on export of parts to ROC reprocessing plant. Memorandum of Conversation, 22 November 1972, in Burr (1999). 
Taiwanese could save resources. ${ }^{7}$ In January 1973, despite US opposition, Taiwan signed a deal with the West German firm UHDE for a spent fuel reprocessing facility. In heated exchanges with the US Ambassador to Germany, Martin J. Hillenbrand, Taiwan's Foreign Minister Shen Chang-Huan maintained that Taiwan had not made a decision about the reprocessing issue and denied the existence of a nuclear weapons program. Under pressure from the West German Foreign Office and the United States, UHDE backed out of the deal in February. The next day, the Taiwanese foreign minister informed the US ambassador that Taiwan had decided not to purchase the reprocessing plant.

In March 1973, the AEC Secretariat's Victor Cheng told the US Deputy Assistant Secretary of State for Far Eastern Affairs, Richard Sneider, that Taipei did not keep 'any nuclear secrets from its friend'. Cheng presented a progress report on building a laboratory scale reprocessing facility at the INER, with a potential capacity to produce approximately 300 grams of separated plutonium per year. ${ }^{8}$ The US estimates came out differently, showing that the Canadian research reactor could generate enough plutonium in one year for a nuclear weapons test if the reactor was running at optimal capacity. A visit by IAEA inspectors in 1976 led to suspicion that the INER may have been secretly diverting spent fuel for reprocessing. In September 1976, the United States made a formal diplomatic request through Ambassador Leonard S. Unger that Taiwan should renounce the development of nuclear weapons. On 17 September 1976, Premier Chiang Ching-Kuo and his cabinet issued a public statement solemnly declaring that Taiwan had no intention to use its human and natural resources for the development of nuclear weapons' or to obtain technology to reprocess spent fuel (United Daily News 1976).

In April 1977, the United States learned that the INER had been in touch with a Dutch firm regarding reprocessing technology. The chief US concerns were about heavy-water production and the 'hot laboratory' at the INER. An IAEA inspector discovered an unsafeguarded exit port at the fuel pond in March 1977, but no spent fuel diversion was found. The United States demanded that Taiwan terminate all fuel cycle activities, reorient facilities to peaceful applications, and transfer all plutonium to

7 US State Department, Proposed reprocessing plant for Republic of China. Cable 2051 to Embassies in Bonn, Brussels, and Taipei, 4 January 1973, in Burr (1999).

8 US State Department, ROC nuclear research. Cable 51747 to Embassies in Taipei and Tokyo, 21 March 1973, in Burr (1999). 
the United States. A team of US experts arrived, tore down all of the suspected facilities, and destroyed the Tao Yuan program. At the same time, AEC Secretariat Cheng visited Washington to discuss the licensing of the first nuclear power reactor. Despite repeated intervention from the United States, suspicion continued. In September 1978, US Secretary of State Cyrus Vance sent a letter to President Chiang concerning suspected activities in the CSSI. President Chiang was obviously annoyed that 'Taiwan's vulnerability and its unique relationship with the US [should] allow the latter to treat [the] ROC [Republic of China] in a fashion which few other countries would tolerate' (United Daily News 1976).

On 12 January 1988, the deputy director of the INER, Chang Hsien-Yi, defected to the United States carrying a large amount of sensitive material. Chang appeared at a closed-door hearing in Washington, arranged by the Central Intelligence Agency (CIA), a few days later. The Taiwanese authorities only learned of Chang's disappearance after this. President Chiang died on 13 January 1988. Two days later, an expert team from the United States visited the INER. They extracted all of the heavy water and thoroughly demolished all nuclear weapon-related facilities. Chang may have been recruited by the CIA and worked in secret for the United States for 20 years before the incident. His defection led to the closure of Taiwan's nuclear weapons program and was highly praised as one of the few covert operations in which the CIA was successful (Weiner 2007). But many Taiwanese view Chang as a traitor.

\section{The civilian applications}

\section{New nuclear power plants}

The organisational framework of nuclear development was established in 1955. Human resources were cultivated at the Institute of Nuclear Science of the National Tsing Hua University. The Institute of Nuclear Science was the only institute in the university, newly relocated from the Chinese mainland. Taiwan signed the Agreement for Cooperation between the Government of the United States of America and the Government of the Republic of China Concerning Civil Uses of Atomic Energy on 18 July 1955, to ensure the transfer of nuclear technologies and materials. The national regulator, the AEC, was established in the same year, on a provisional organisation status, with the majority of its 
personnel seconded from other ministries. The Department of Nuclear Engineering at the National Tsing Hua University was established in 1964, and began recruiting undergraduates. The timing coincided with the start of the Hsin Chu project and the establishment of the CSSI.

Site selection for nuclear power plants, mentioned earlier, began in 1964. In 1969, with help from IAEA experts, Chin San and Yen Liao were found to be suitable and the former was preferred (CEPD 1979). Bechtel Corporation was contracted to provide support for site selection, machinery, and instrument preparation, in addition to technical and economic feasibility studies. Two GE LWRs, $636 \mathrm{MW}$ each, were recommended for the Chin Shan nuclear power plant project, and received formal approval from the Executive Yuan in August 1969. It was one of Taiwan's 'ten major infrastructure projects', an achievement of Premier Chiang Ching-Kuo, who later succeeded his father as president (Small and Medium Enterprise Administration, Ministry of Economic Affairs n.d.).

The second (Kuosheng) and third (Maanshan) nuclear power plants went forward without dispute. Total installed nuclear capacity reached 5,144 MW when the Maanshan plant was in full operation in 1985. The fourth nuclear power plant project, Lungmen, was approved in September 1980, with the intention of connecting to the grid by 1994 .

Since nuclear power plants were meant to be a distraction from weapons development, the Taiwanese authorities paid little attention to the actual trend of electricity demand. The reserve margin for electricity-the percentage of installed capacity that is not needed even during periods of annual peak demand-suddenly jumped to 55 per cent in 1985 when the Maanshan plant began feeding electricity to the grid (Control Yuan 2012). It was estimated that over 70 per cent of electricity-generating capacity was left idle for most of the year. The addition of two more huge nuclear reactors was completely unnecessary. Fifty-five KMT legislators appealed for an emergency motion to halt the Lungmen program (Legislative Yuan, Atomic Energy Council 1985). Their concerns, including operational risk, nuclear waste management, and energy security, were presciently similar to current anti-nuclear rhetoric. The premier dutifully complied and indicated that there was 'no need to start until all suspicions are cleared', so the Lungmen program was retracted (Legislative Yuan, Atomic Energy Council 1985). 


\section{A shifting line of command and a partisan political issue}

The defection of the deputy director of the INER, the death of President Chiang Ching-Kuo, and the total destruction of Taiwan's nuclear weapons program all happened within one week in early 1988 . Not only were these inconceivable shocks for Taiwan's nuclear weapons proponents, but huge political changes were also expected. Perhaps too embarrassed, or too busy with power struggles to care about the future of nuclear energy, military personnel have cut their involvement with nuclear power since then. Without any challenge from other agencies, Taipower with its hefty cash coffer conveniently took over the decision-making role.

In the following years, installed electricity capacities mysteriously shrank; as much as 3.8 gigawatts $(\mathrm{GW})$ in estimated capacity was taken offline between 1986 and 1991 (calculations based on open data provided by Taipower n.d.a). As a result, the reserve margin fell from 55 per cent to 4.8 per cent. Unexpected power outages and rolling blackouts became routine and occurred with increasing frequency (Central News Agency 1991a, 1991b, 1992a, 1992b). The Lungmen nuclear power plant program was revived as the most viable option to rescue Taiwan from power shortages. Analyses by the Chung-Hua Institution for Economic Research (Wang 1991) showed the error in this thinking-they found that the majority of blackouts were caused by malfunctions of nuclear plants. Taipower was criticised for deliberately creating power shortages in order to gain support for nuclear power expansion (Central News Agency 1994, 1995). Despite this, the authority planned to install eight more nuclear reactors by 2020 (Gi 1998), including the two in Lungmen.

After the Chernobyl nuclear disaster in 1986, people began to realise the risks associated with nuclear power. When the Lungmen nuclear power plant program was revived in 1990 , it met with much public suspicion, as more people spoke out about nuclear safety issues. The DPP, Taiwan's first real opposition party, was formed in September 1986, and had antinuclear party guidelines to 'oppose any program to install a new nuclear reactor; encourage the development of alternative energy resources; and set [up] a timetable to close all nuclear power plants' (Democratic Progressive Party Principles and Guidelines n.d.: 13). When, in June 1992, the KMT majority in the Legislative Yuan hammered through an eight-year budget for the nuclear project, the Lungmen nuclear power plant project became a partisan issue, with the DPP strongly opposed. DPP member Chen 
Shui-Bian won the presidential election in May 2000 and, keeping his campaign promise to residents near the planned Lungmen site, terminated the program on 27 October 2000.

The termination announcement was made after Chen met with Lien Chan, chair of the KMT opposition. Lien was not informed of Chen's decision beforehand and felt that he had been publicly humiliated. The KMT not only launched an all-out campaign against Chen's decision, it also initiated an impeachment process in the KMT-dominated Legislative Yuan. President Chen bowed to sustained pressure, and the Lungmen program resumed in February 2001. ${ }^{9}$ The failed attempt to stop Lungmen was seen as a major setback for the ruling DPP. Subsequently, key politicians have been reluctant to get involved in issues related to the Lungmen program.

\section{The problematic history of the Lungmen nuclear power plant}

\section{Construction flaws}

Construction of the Lungmen nuclear power plant revealed the strained relationship between the regulator, the AEC, and the operator, Taipower. The three existing nuclear power plants were completed under the supervision of US consulting firms Ebasco and Bechtel. With very little experience, Taipower undertook the construction of the Lungmen nuclear power plant using GE blueprints. The equally inexperienced AEC set up a regulatory committee in January 1997 to monitor Lungmen's quality and progress. The AEC began publishing short monthly monitoring reports in 2002, when the real work started. Many of the flaws identified during the early stages of the construction were quickly corrected. The first major discovery was triggered by anonymous tips, pointing to the lower-thanrequired-strength welding applied to the reactor base frame (AEC 2002). Follow-up by the AEC in April 2002 confirmed the problem, so the base frame was rebuilt.

9 Premier Chang Chun-hsiung and Legislative Yuan Speaker Wang Jin-pyng signed an agreement to resume construction, and the decision was announced the day after. 
An increasing number of flaws were identified as construction progressed. Major problems listed in the AEC's reports included reinforced tendons for a containment anchor being accidentally cut (AEC 2007), and careless contractors repeatedly setting working platforms directly on top of installed pipes and tubing, causing rust, obvious dents, and even punctures (AEC 2008a, 2008b, 2010). Workers' logs were completed with clearly too much work that could be finished in a single day (AEC 2009). Moreover, many joints inside the Lungmen reactor building were inadequately sealed with Teflon tape (AEC 2011).

However, more serious allegations raised by an insider were categorised by the AEC as 'not safety related' (AEC 2008c). These included headlinegrabbing design alterations and the systematic cutting of corners on materials (Wang and Wei 2008). It was found that Taipower had made 395 alterations to the Lungmen nuclear power plant design, including support for an emergency cooling system, without consulting the AEC or GE. In addition, Taipower knowingly used neoprene gaskets instead of carbon fiber gaskets in pull box and conduit fittings, despite the fact that the specification clearly precludes using such gaskets. The former can easily be ignited with a cigarette lighter, whereas the latter can endure temperatures of up to 1,000 degrees Celsius. It was also found that hot dip-galvanised zinc steel was replaced by zinc-electroplated steel: the coating on the former is 25 times thicker than that on the latter, and can last more than 50 years in coastal areas. In reply to questions from journalists, the Taipower Lungmen site manager said that a nuclear power plant is not a humid environment, zinc-electroplated steel is adequate, and neoprene releases toxic fumes when it catches fire. Since no one could survive such high temperatures, this concern seemed spurious (Wang and Wei 2008).

The AEC imposed a fine of NT $\$ 500,000$ (about US\$16,700) on Taipower in April 2008, and insisted that Taipower re-evaluate the safety of altered items and make no more alterations without the AEC's consent. ${ }^{10}$ A couple of months later, the AEC discovered that Taipower had made about 700 additional alterations without the AEC's knowledge. A total fine of NT\$3.5 million (about US\$117,000) was imposed..$^{11}$ Yet again, more alterations without authorisation were discovered in mid-2011

10 The AEC website lists the penalties and fines of confirmed violations and irregularities related to nuclear plant operation and construction.

11 Violation nos 0970020065 and 0970020065 , issued 19 November 2008. 
(Lee 2011). This time, the AEC not only imposed a higher fine of NT $\$ 15$ million (US\$500,000), but also announced that it would take culpable Taipower executives to criminal court. ${ }^{12}$ Apparently, Taipower holds little respect for the AEC.

\section{Shared irresponsibility}

Although Taipower is a state-owned utility monopoly, few government administrations have had firm control of its management. Magazine interviews with several Taipower executives in June 2008 revealed the rationale behind the alterations at Lungmen (Lee 2008). They blamed 'GE's over-conservative design' for all the problems. ${ }^{13}$ The excessive GE design, the executives said, required 'tens to thousands of times more [materials] than the project really needed', making 'construction difficult' and 'inflating the costs'. ${ }^{14}$ Also, GE designs apparently could not be trusted since the United States had not constructed a new nuclear power plant in 30 years, during which 'GE lost a major part of its nuclear capability'. Taipower executives claimed that they had found 'numerous contradictions' during construction, and therefore 'had no choice but to make improvised changes in order not to delay the whole project' (Lee 2008).

The AEC had overlooked some important issues. In the short inspection reports in May and August 2007, the AEC mentioned only in passing the poor cement jobs in both reactor containments. Reports described threaded steel, cigarette butts, and plastic bottles found in the wall of the reinforced concrete containment vessel, with no photos attached. Some places had steel bars partially exposed. Also found in Unit-1 were workers chipping away at the newly built containment, with over 40 tendon steel bars cut, to make room for the spent fuel pool. It was not until a photograph that showed a plastic bottle in the containment wall was leaked to the press in April 2013, that people began to realise how potentially catastrophic and dire the situation was.

12 Violation no. 1010001075, issued 16 January 2012.

13 Interview with Shih Hung-gee, who served as general manager of the Maanshan nuclear power plant, chief engineer of the Lungmen nuclear power plant, and deputy chair of Taipower. After retiring in 2009, Shih stayed on as an advisor for Lungmen (Lee 2008).

14 Explained by Lin Jun-long, head of the Lungmen nuclear power plant Progress Oversight Unit at Taipower (Lee 2008). 
According to the AEC, a fine of NT $\$ 400,000$ (about US $\$ 13,000$ ) was imposed, the plastic bottle was removed, and the holes were filled with equal-strength concrete. The AEC assured the public that the strength of both containments was not compromised even after modifications (AEC 2014). Less than two weeks later, however, reports were published of a failed integrated leak-rate test and structure integral test for Unit-1 between 26 February and 5 March 2014 (Tang and Chien 2014). Leaks were substantial, but difficult to locate. Suspected causes ranged from more unseen plastic bottles in containments, second-hand valves, and construction short-cuts on the penetration seal within the nuclear island. In addition, records showed that as many as 197 items had been moved from Unit-2 to Unit-1 to replace broken parts, probably as a result of inadequate handling.

As construction at Lungmen began, scandals came to light from time to time, but public reaction was rather mild. In 2008, Ma Ying-Jeou of the pro-nuclear KMT won the presidential election, and began earnestly to pursue the task of making the Lungmen nuclear power plant operational. Nuclear energy was framed as an indispensable part of the climate mitigation program, and more nuclear power was suggested (Ho 2008). Although grid connection time was postponed repeatedly (Central News Agency 2014), work nevertheless continued.

\section{Lungmen nuclear power plant's demise}

The Fukushima disaster of March 2011 completely changed the situation. People suddenly realised how much Taiwan and Japan had in common, especially regarding seismic vulnerability. Many were bewildered as to how a prudent society with such advanced technology could become so helpless, and what would become of Taiwan in a similar situation. Immediate responses from the AEC were anything but reassuring. Without any evaluation, and just two days after the Fukushima disaster, the AEC deputy chair boasted that 'all nuclear power plants in Taiwan are as sturdy as Buddha sitting on his platform' (Now News 2011). Neighbouring countries, such as the Philippines, Vietnam, and China, all had detected radioactive materials from Fukushima, but the AEC insisted that nothing was detected until 31 March $2011 .{ }^{15}$ The sensitivity of the AEC's instruments was questioned by the public (Yen et al. 2011).

15 In response to a legislator's question about whether radioactive material would come to Taiwan, deputy chair Huang Ching-tong of the AEC said, 'No radioactive substances will reach Taiwan, since the Japanese have not had enough for themselves' (Tung Sen News 2011). 
In February 2013, the KMT's premier proposed holding a referendum to settle the future of Lungmen nuclear power plant. The Referendum Act of Taiwan requires more than 50 per cent voter turnout, plus an absolute favourable majority vote, in order for the referendum to be legally binding. Since the law passed in 2006, six national referenda have been held and all were rejected because turnouts were between 26 and 45 per cent. Under the current law, framing of the referendum question determines the outcome. The KMT's proposal was as follows: 'Do you agree that the construction of the Fourth [Lungmen] Nuclear Power Plant should be halted and that it not become operational?' Having the intended ballot date set at the end of 2013, the administration calculated that few would come to vote solely for the referendum, thus legitimising the project.

Meanwhile, the AEC requested that the European Union (EU) perform a Taiwan 'stress test', to be completed one month before the planned voting date. A well-received international assessment certainly would win more public support. Some concluded that the Taiwan stress test was a propaganda exercise and not for nuclear safety. Non-governmental representatives discovered that geological information in the AECprepared Taiwan stress test national report was much shorter than what was already known. Distances between nearby faults and nuclear reactors were either overlooked or completely absent in the report (AEC 2013; Tsai 2013; Hsu 2013). In the end, the AEC received a polite and lukewarm assessment report (ENSREG 2013). But waves of demonstrations occurred nationwide, including an anti-nuclear protest on 9 March 2013, which drew a crowd of more than 200,000 people.

Pressure from the electorate forced KMT legislators to withdraw the referendum proposal (Shih 2013). But a controversial service trade agreement with China that KMT legislators passed very quickly renewed widespread demonstrations in March 2014. On 22 April 2014, Lin YiHsiung, former DPP chair and long-time anti-nuclear activist, went on a hunger strike, calling for the termination of the Lungmen nuclear power plant. Under all this pressure, President Ma Ying-Jeou reluctantly made concessions on the project, including ceasing construction and sealing of Unit-1 pending a later decision, and completely stopping construction of Unit-2 (M.-S. Huang 2014). The latter decision was probably made because the administration was clearly aware that the possibility of Unit-2 becoming operational was very slim. Lin ended his hunger strike on 30 April 2014. 


\section{Radioactive-contaminated buildings}

Checking whether property for sale is radioactively contaminated may not be common elsewhere, but in Taiwan it is a regular service provided by real estate agents. Since 1992, more than 300 buildings in Taiwan, including 1,600 apartments, have been identified as being contaminated with elevated levels of radiation. The widespread radioactivity in housing resulted from repeated negligence and a cover-up by AEC personnel for over a decade. The AEC first learned about the existence of radioactive steel in January 1983. Steel bars bought by Chin San nuclear power plant were found to be highly radioactive, with radiation levels of 70 microSievert per hour $(\mu \mathrm{Sv} / \mathrm{h}$, approximately 700 times background levels of around $0.1 \mu \mathrm{Sv} / \mathrm{h}$ ). ${ }^{16}$ The supplier, Chin San Steel, bought steel ingots from a steel factory in Taoyuan. The AEC learned that Chin San Steel had sold two tonnes of steel bars to Chin Shan nuclear power plant and 29.9 tonnes to Jien-Kang Construction Company for the Tien Mo dormitory of the International Commercial Bank of China. Readings on unused steel bars on the construction site were about $50 \mu \mathrm{Sv} / \mathrm{h}$, and those of the half-built dormitory ranged from 1 to $5 \mu \mathrm{Sv} / \mathrm{h}$ in March 1983 .

The AEC swiftly demanded that the construction company remove all installed radioactive steel bars. On 26 March 1983, the AEC made Jien-Kang Construction and Chin San Steel promise to safeguard both 17.2 tonnes used and 12.7 tonnes of unused radioactive steel bars in the Chin San Steel warehouse, with no transfer to be made without the AEC's permission. However, an AEC inspector visited the Chin San Steel warehouse on 24 May 1984, and found that all of the unused radioactive steel bars were gone, allegedly sold without prior consent from the AEC. In his reply to the AEC's inquiry, the owner of Chin San Steel claimed that the entire supply of steel was far too rusty to be useful and therefore it was buried on-site. The AEC seemed to be persuaded, and it did not follow-up on this issue.

On 15 August 1992, the public first learned about a 'radioactive' villa in the Liberty Times (Chang, Chan, and Wang 1997). A tip-off from a disgruntled AEC employee led a reporter to a building called the Ming Shan Villa. Radiation levels as high as $600 \mu \mathrm{Sv} / \mathrm{h}$ were found, emanating from the building frame, about 300 times higher than the limit for

16 The permissible limit in Taiwan for workers in nuclear power plants is 100 milliSieverts (mSv) in five years. Six hundred $\mu \mathrm{Sv} / \mathrm{h}$ is equivalent to 5.26 sieverts (Sv) per year (5260 mSv/year). 
workers in nuclear facilities. It was soon discovered that the AEC had known about the incident since March 1985 when an AEC contractor was sent to evaluate the X-ray machine installation in a new dental clinic (Wang 1996). With the X-ray machine switched off, the radiation level reading was $280 \mu \mathrm{Sv} / \mathrm{h}$. The inspector quickly realised the readings came from the building beams. Saying nothing to the dentist, he reported back to the AEC with his sketch of the radiation distribution. Fearing that the radioactive steel beams were those that had disappeared in the commercial bank case one year earlier, the AEC chose to cover it up. ${ }^{17}$ It issued the dentist a regular licence and decided not to carry out any future sampling in that building. The AEC also extracted promises from everyone, including the contractor and the X-ray machine dealer, not to reveal those measurements to the public. The dental clinic received AEC licence renewals several times subsequently.

After seeing the Liberty Times report, the AEC tried to downplay its seriousness by referring to the radiation level found in Ming Shan Villa as 'slightly above background level' (Central News Agency 1992c). Only after more details were leaked to major media outlets did the AEC reluctantly admit that the radiation level was 1,000 times higher than background from radioactive cobalt-60 with a half-life of 5.2 years (Central News Agency 1992d). A frantic nationwide radiation monitoring effort began. Identified radioactive-contaminated buildings included business offices, kindergartens, schools, and residential homes. Around 13,300 residents have been exposed to radiation. Meagre support and multiple criteria set by the AEC for rebuilding ${ }^{18}$ have resulted to date in less than 7 per cent of buildings being rebuilt, and 15 per cent adding lead shields or having radioactive steel bars replaced. About 80 per cent of the contaminated buildings have been left intact, including Ming Shan Villa. Twenty years after the news emerged, 3,600 dwellers still reside in radioactivecontaminated apartments. ${ }^{19}$ It seems that the AEC wishes to let nature solve this messy travesty.

17 Many dispute this because the reading in Ming Shan was much higher than that in the International Commercial Bank of China case.

18 Apartments with an annual dosage above $25 \mathrm{mSv}$ are acquired by the government; those living where the annual dosage is $5-25 \mathrm{mSv}$ receive compensation of NT\$200,000 (about US\$6,667). No compensation is provided where the annual dosage is below $5 \mathrm{mSv}$. Only buildings with more than 20 per cent of apartments above $5 \mathrm{mSv}$ per year are eligible for better floor-area ratio if rebuilt. 19 With a half-life of 5.2 years, radiation levels reduced to 6.7 per cent of the original level 20 years ago. Therefore, the original radiation level is 2.54 times higher than seven years ago, when the AEC first learned about the problem. 


\section{Sources of radioactive materials}

Where did these radioactive materials come from? Most radioactive steel bars were produced between 1982 and 1983 by Hsin Jung Steel Company, in Taoyuan county, and derived from scrap metal. Hsin Jung Steel claimed that no imported scrap metal was used during that period. An AEC investigatory report pointed a finger at the Army Chemical Infantry School, not far from Hsin Jung Steel (Lee 1984). The school reported that one of the cobalt-60 sources of 23.8 Curie was missing in September 1982, and the radioactive steel bars were first found on the market one month later. The AEC thus conveniently suspected that the school might have lost more than one of the cobalt- 60 sources of 23.8 Curie, and specifically ruled out the possibility that radioactive materials might have come from its Institute of Nuclear Energy Sciences, which is closer to Hsin Jung Steel. An Army spokesman denied the accusation (Lin 1984).

Radiation Safety Improvement Organisation, a non-governmental organisation, challenged the official report. ${ }^{20}$ According to its calculation, a couple of radiation sources can generate no more than a few hundred tonnes of steel, far less than the 7,000 tonnes that the AEC had already identified. Among leaked AEC confidential files were the inventory books of Hsin Jung Steel dating from 1982 to 1983, which the AEC seized in its 1985 internal investigation of the Ming Shan Villa incident. Records showed that Hsin Jung Steel had purchased 604 tonnes of scrap metal from Taipower on 29 October 1982. In November 1982, Hsin Jung Steel sold the steel to various construction companies; all were later identified as radioactively contaminated. Approximately 6,000 tonnes of scrap steel were collected after annual maintenance at the three operating nuclear power plants. Taipower denied that the scrap steel sold was radioactive plumbing, but offered no explanation as to where the scrap steel went.

Residents of Ming Shan Villa filed a petition with the government's Control Yuan against the AEC. In June 1994, the Control Yuan passed a resolution condemning the AEC bureaucrats (Control Yuan 1994). The accused were sent to the Public Functionary Disciplinary Sanction Committee, and the Supreme Prosecutor's Office was asked to investigate possible administrative and/or criminal responsibilities. However, judges

20 Wang Yu-lin is chair of the Radiation Safety Improvement Organisation. 
found the AEC bureaucrats innocent on the grounds that 'steel bars are not under AEC jurisdiction, nor is the radioactive contaminated steel' (Control Yuan 1994).

\section{Low-level nuclear waste on Orchid Island}

Orchid Island ( $\mathrm{Lan} \mathrm{Yu}$ ), where the aboriginal Tao tribe resides, is situated in southeastern Taiwan. A low-level nuclear waste ${ }^{21}$ temporary storage facility was constructed there in 1978, disguised as a fish cannery. It began operating in May 1982. The initial plan was to dump the waste into deep ocean trenches adjacent to Orchid Island. But the 1993 Amendment to the Convention on the Prevention of Marine Pollution by Dumping of Wastes and Other Matter added low-level nuclear waste to the black list, and the dumping plan was abandoned (LanYu BiWeekly 1996). ${ }^{22}$

However, low-level nuclear waste kept being sent to the island. It was alleged that workers were permitted to release liquid radioactive waste into the surrounding environment. Since the original plan was to dump the nuclear waste into the ocean, drums were made of ordinary steel. In this hot, humid, and salty environment, about one-third of the waste barrels showed clear signs of rusting by early 1995 . Locals complained about increasing numbers of cancer-related deaths and cases of children with learning disabilities. Taiwan's National Health Statistics indicated that Orchid Island has the highest cancer death rate in Taiwan (Chiu, Wang, and Liu 2013). Feeling deceived and abandoned by the government, the Taos began protests in 1988, which soon gathered momentum. On 27 April 1996, the Taos successfully prevented Taipower's low-level nuclear waste shipments from docking. No more waste shipments to Orchid Island have occurred since then. By that time the total number of nuclear waste barrels stored was 97,672.

Taipower first promised that a permanent low-level nuclear waste disposal site would be identified in 1996, and that all nuclear waste would be removed from Orchid Island by 2002. This target was also one of the

21 According to the AEC's definition, all radioactive materials except spent fuel are categorised as low-level waste, including equipment and materials that have had direct contact with fuel.

22 This international convention was established in 1972 and entered into force on 30 August 1975. The United States and Japan agreed to ban marine dumping of low-level nuclear waste after learning that the Soviet Union dumped about 900 tonnes of low-level nuclear waste into the Sea of Japan prior to 1993. A global ban on all dumping of radioactive waste at sea came into force in 1994 . 
conditions attached to the approval of Lungmen nuclear power plant's Environmental Impact Assessment (EIA). However, in an EIA revision submitted in July 2001, Taipower argued that permanent low-level waste storage was relevant neither to the operations of Lungmen nuclear power plant, nor to its environmental impact. Taipower successfully had the condition removed. The revision took place immediately after the KMT lost the presidential election, after five decades in power. In the ensuing political chaos, Taipower's revision received little attention.

Taiwanese authorities made a number of attempts to locate a permanent low-level nuclear waste site. A search panel for Taipower first identified Hsiao Chiu in Kingmen county as the most suitable site in 1998. After the DPP won the general election in 2000, the new AEC chair objected to the location as too close to China, potentially causing unwanted tensions (Liu 2002). Several legislators even suggested paying the aboriginals to leave Orchid Island, and to use it as a permanent nuclear waste site. Officials quickly denied having such a plan (Lo 2002). Exporting the waste was also seriously considered. In 1997, Taipower signed an agreement with North Korea for the latter to store 60,000 barrels of lowlevel nuclear waste from Taiwan. Nothing came of this proposal, since the North Korean facility was not ready in time, and South Korea issued strong protests.

There was speculation that China offered help on low-level nuclear waste storage, and that the waste might be sent to Solomon Islands, or the Marshall Islands. Nevertheless, no substantive solution materialised. Commencing in 2000, Taipower began paying NT\$220 million (US\$7.3 million) every three years to rent the waste storage site (Taipower n.d.b). An Orchid Island Storage Facility Relocation Committee was established under the Executive Yuan in May 2002. Meanwhile, the condition of the drums on Orchid Island continued to deteriorate.

A repackaging program was begun in 2008. Most canisters were found to be rusted, broken, and some even shattered. Although all the waste had been on Orchid Island for more than 10 years, the readings on sampled barrels were 2-4 milliSievert $(\mathrm{mSv})$ per hour. A couple of hours of exposure would exceed the maximum annual dosage allowed for nuclear workers. However, the majority of the repackaging work was done by unskilled temporary labourers who were only provided with a simple dust-free suit, not radiation-protective gear. Instead of using a negative pressure chamber, everything was carried out in the open air. Workers wore regular clothing 
when applying new paint to the repacked canisters. Taipower's reason was that there was no 'dust' in the vicinity. The existence of the poor working conditions were made public during a Legislative Yuan hearing. The AEC chair first mocked legislators for using outdated information (CTI 2012). After enough evidence was presented, the AEC chair admitted that he was wrong (AEC 2012).

It is not clear whether the AEC was just too lax and incompetent to be aware of the poor working conditions, or whether it knowingly tried to cover-up this issue. Either way, serious negligence occurred at Orchid Island. There are 100,277 barrels after repackaging. Thirteen years have passed and promised completion dates have consistently failed to be met. The Taos are stuck with the low-level waste. Their experience provides a vivid example of problems that can be encountered when allowing nuclear waste to be stored in communities.

\section{High-level nuclear waste: Conflict of interest}

Over the past three decades, all spent fuel from nuclear power plants has been stored in the spent fuel pools next to the reactors. To date, the four reactor spent fuel pools have only enough room for an additional 9, 7, 34, and 146 fuel assemblies (AEC 2016). It is thus impossible for those reactors to have a whole core removal in case of an emergency. After the Fukushima disaster, both the AEC and Taipower understand very well the dire situation of having four fully loaded spent fuel pools. Somehow, they have let those reactors continue operating.

Taipower anticipated the lack of storage space for the spent fuel two decades ago. Four types of dry casks for spent fuel interim storage were listed in its EIA reports for Interim Dry Storage of Spent Fuel from Chin Shan and Kuosheng nuclear power plant, submitted in March 1995, and permission was received in June 1995. According to Taipower, the dry cask contract has been open for international tenders four times since 1995 . It failed to find qualified tenders at a 'reasonable' price. Therefore, the contract was given to the INER, a deal which the AEC argued complied with the law. The INER is Taiwan's only nuclear energy research institute and does not work on nuclear regulation. All of the INER staff involved in the dry cask project are excluded from making an assessment, leading the AEC to argue that no conflict of interest exists (INER 2015). 
In 2005, Taipower submitted its environmental change and countermeasures report, a revision of an earlier EIA, ${ }^{23}$ and cement casks were chosen for both Chin Shan and Kuosheng nuclear power plant (Taipower 2005). Permission was granted in September 2008. Instead of having enough dry casks to store all possible spent nuclear fuel generated, the revised plans cover less than one-fifth of the overall spent nuclear fuel. ${ }^{24}$ The change strengthened the suspicion that the interim dry cask program was intended only to prolong reactor lifetime (Wei 2005), rather than for reactor decommission. An application for lifetime extension of the Chin Shan nuclear power plant was submitted in 2009 (Chung 2009).

The cement cask that Taipower chose consists of one stainless steel container, $1.59 \mathrm{~cm}$ thick 304L steel, plus two outer layers of reinforced concrete. According to Taipower, the dry casks will stay intact for 40 years in open air, next to the ocean. Taipower is so confident that it only plans to install temperature sensors on each cask and one radiation detector for the whole storage area of 30 units. All processes were evaluated using computer simulations. Requests for a few experimental validations were rejected as unnecessary. Also deemed unnecessary are back-up plans and related facilities. Local residents worry that these interim storage sites may become permanent high-level waste dump sites. In response to concerns of its constituency, the New Taipei City government has held the required Land and Water Conservation License for the dry cask storage since 2013 (Lai 2013). ${ }^{25}$ Meanwhile, the spent fuel pools in Chin Shan and Kuosheng nuclear power plants keep piling up.

Unexpectedly, the United States recently offered Taipower another option, making use of the 1955 nuclear cooperation agreement. That agreement, based on Section 123 of the US Atomic Energy Act, included nine nonproliferation criteria, prohibiting Taiwan from operating sensitive nuclear

23 The law requires that projects that pass EIA but do not start within three years must send an environmental change and countermeasures report for reassessment.

24 Environmental Protection Administration, Taiwan (2008) reduced the number of spent fuel bundles to be stored from 8,448 to 1,680; Environmental Protection Administration, Taiwan (2009) reduced the number of spent fuel bundles to be stored from 13,840 to 2,400 bundles.

25 Required by law, the prospective dry cask storage site has to complete all land and water conservation requirements set by local government. Taipower submitted a licence request to the New Taipei City after finishing ground preparations for dry cask in Chin San nuclear power plant in July 2013 (Lai 2013). 
facilities and from any activities involving sensitive nuclear technologies. ${ }^{26}$ The agreement was renewed on 6 January 2014 and entered into force on 22 June $2014 .{ }^{27}$ For the first time, the agreement allows irradiated source material or special fissionable material to be transferred from Taiwan to France, or other countries or destinations for storage and reprocessing. A similar provision was recently included in Section 123, and in an agreement between the United States and the United Arab Emirates.

With the backing of the new US-Taiwan 123 Agreement, as it is called, Taipower then announced a tender invitation for reprocessing on the last working day before the lunar New Year holiday (17 February 2015), fully aware that no budget was allocated for this project. Taipower's behaviour met objections from both sides of the Legislative Yuan. A legislative resolution forbids tender soliciting unless a reprocessing budget passes the review. However, a tender request for reprocessing project bids remained on the public procurement site with a due date of 9 April 2015. Only after mounting public uproar did Taipower and the Ministry of Economic Affairs retract the announcement on 1 April 2015.

Generally speaking, a legally binding gold standard in the nuclear cooperation agreement will help establish a global precedent that enrichment and reprocessing are not necessary for a civil nuclear program. However, a substantial amount of high-level waste will remain even after reprocessing, so it must be dealt with carefully. Reprocessing does not solve the current high-level waste dilemma; in a global perspective, reprocessing only adds to the existing stockpile of fissile materials, increasing the risk of their becoming prey to terrorists and intensifying global vulnerability. The only advantage of reprocessing is to postpone high-level waste problems by two to three decades; the odious problems are then offloaded to future generations.

26 Under the 1955 agreement, sensitive nuclear technology is defined as any information or facility 'designed or used primarily for uranium enrichment, reprocessing of nuclear fuel, heavy water production, or fabrication of nuclear fuel containing plutonium'. These processes have the potential to be used not only for civil power generation but also for building a nuclear weapon.

27 The agreement is between the American Institute in Taiwan, which represents US interests in the absence of an embassy, and the Taipei Economic and Cultural Representative Office (TECRO) in the United States. Under the Taiwan Relations Act 1979, the United States concludes executive agreements such as Section 123 with TECRO. 


\section{Conclusion}

The aforementioned absurdities and travesties of decision-makingthe apparent abandonment of assigned responsibility by the regulator and the over-zealous pursuit of nuclear energy of the operator-are reminiscent of failed weapons programs. In the early 1960s, nuclear engineering was a glorified and prestigious discipline, in which only the brightest students had the chance to participate. There were ample job opportunities waiting for them in research institutes, government, and utility companies. The government's move away from military applications cut job opportunities. Nuclear accidents in Chernobyl and Three Mile Island turned many prospective students away. To boost its undergraduate recruits, the Department of Nuclear Science at the National Tsing Hua University had its name changed twice, in 1995 and 1997, finally becoming the Department of Engineering and System Sciences.

Most of the senior staff in the AEC and Taipower were the top students, who at the start of their careers were full of enthusiasm for nuclear energy. Their career advancement was unfortunately stopped by domestic and international circumstances. Some felt they had been victimised and became cynical. Some were angry with the 'arrogant' Americans who had destroyed years of hard work, in a supposedly secret weapons program. Some were over-confident and eager to prove that they could exceed the capabilities of their US counterparts, such as those who altered GE designs for the Lungmen nuclear power plant. Overall, these workers seemed to have suffered from a subtle 'Boxer mentality. ${ }^{28}$ On the other hand, with the increased difficulty of recruiting fresh talent, jobs were left to fewer and less qualified personnel to handle all of the increasingly complicated operations and regulations. Unskilled workers were routinely assigned to power plant maintenance and waste management, as in the Orchid Island low-level waste repackaging program. Once projects were contracted out, Taipower showed little interest in understanding the workers' qualifications, workplace safety, or working conditions. All nuclear-related checkups were left to a handful of AEC inspectors.

28 'Boxer mentality' describes under-equipped people or groups of people who resort to irrational and rudimentary behaviour against long-term exploitation, humiliation, or suppression. It is a widely used phrase in Chinese-speaking society, derived from the Boxer Rebellion in China (1898-1901), which opposed Western imperialism and Christianity. The Boxers were barely armed but claimed to possess supernatural protection from firearms. They were manipulated by the Qing dynasty empress to declare war on foreign powers. 
Taiwan's regulator, the AEC, was established in 1955 basically as a liaison office for international communications. On paper, the AEC is in charge of everything related to nuclear energy except operations, from promoting nuclear research and development, reactors, and nuclear fuel assessment, to radiation monitoring and licensing. In reality, the military ran the CSSI, taking orders directly from the top, and making key decisions on nuclear research and development. Even after the INER moved from the CSSI to the AEC, the latter remained in a supporting role.

Military involvement was severed after the defection of the INER's deputy director Chang, the death of President Chiang Ching-Kuo, and the total destruction of Taiwan's nuclear weapons program in early 1988 . Taipower took over the leading role of promoting nuclear energy. The rhetoric of 'only nuclear energy can save Taiwan from electricity shortage' has been used repeatedly in the past, such as in the Lungmen nuclear power plant revival, during nuclear debates (Lin 2011), and in the months leading up to the general election (Huang 2015). In 2015, Taipower issued stern warnings on potential electricity shortages in early summer (Chen 2015). These warnings were undercut when it was found that power plants providing as much as $2.9 \mathrm{GW}$ were scheduled for routine maintenance between May and September, a time of peak demand (Wang 2015). ${ }^{29}$

Since the DPP gained control of the government in 2000, earlier hopes of introducing eight more nuclear reactors faded away. For nuclear proponents, having both the Lungmen nuclear power plant operational and the lifetime extension of existing reactors was their second-best option. President Ma's reluctant decision to terminate the Lungmen project in April 2014 left them with only one option for 'nuclear growth'-the lifetime extension of existing reactors. Even the AEC chair stated that reactor lifetime extensions are necessary to ensure enough electricity supply (Tang 2014).

President Tsai's promise of going nuclear free by 2025 means the end of reactor lifetime extension (C.-W. Huang 2014). ${ }^{30}$ But even with spent fuel pools full, Taipower is unwilling to shut reactors down before the expiration dates, as this might be seen as a total retreat for the nuclear

29 For real time information on power production, see Taiwan Power Company (n.d.).

30 Mr Chang Jia-Ju, Minister of Economic Affairs, wondered whether the public would accept blackouts in the event that Taiwan goes nuclear free. 
industry. Perhaps the situation is so unbearable for nuclear proponents that they are willing to put the whole society at risk to prevent it from happening.

Secrecy is another problem. It was extremely important to keep the nuclear weapons program moving and free from foreign meddling. Nothing should be revealed to outsiders. To conceal the true intentions, or even to mislead foreign counterparts, a misinformation campaign was initiated. Habitual denial became a reflex. Public health, safety, credibility, and other societal issues became a distant second priority. Some level of sacrifice was deemed necessary. The AEC did whatever policy required of it.

Although the nuclear weapons program was axed nearly three decades ago, the culture of secrecy, denial, and deceit still prevails. As can be seen from the examples provided, most AEC executives still maintain old habits - willing to support prevailing behaviour rather than independently assert the AEC's regulatory powers. The AEC thus provided outdated information in the Taiwan stress test national report, chose to be ignorant of the Orchid Island repackaging conditions, understated the condition of the Lungmen containments, and concealed the Ming Shan Villa records and others. The welfare of ordinary citizens did not and does not enjoy high priority; maintaining the status quo comes first. But, as a result, distrust in government grows, creating further barriers to policy implementation.

In practice, this type of insular organisational culture encourages negligence in work places, weakens safety regulations, invites accidents, and puts the entire society at risk. The many details of dangerous events came to light owing to hundreds of insiders and volunteers who provided key evidence of misconduct to prevent the situation from getting worse, perhaps just in time. But dependence only on whistleblowers and volunteers to correct wrongs is not healthy for Taiwan politically or socially. Moreover, it is unreliable as a check against misinformation and negligence, being far too risky as a guarantor of public safety.

Now is a critical time for the nuclear industry. On the one hand, some industrialised countries have decided to go nuclear free after the Fukushima disaster. On the other hand, many less technically advanced and less transparent countries plan to introduce or expand civil nuclear programs. Managing nuclear power is much more complicated than other 
types of energy utilities. It requires constant care and vigilance in every respect and can only be sustained by a large number of well-qualified human resources. Many established nuclear countries are already facing a rapidly shrinking supply of well-trained personnel to maintain routine operations, as well as to handle nuclear waste and decommissioning. For the new entrants to nuclear power, there are increasing worries that they may not have sufficient technical capabilities to oversee the construction and safe management of nuclear power. The more important question is whether or not a system of checks and balances is well-established in their national framework. Some of the newcomers have a political system similar to that of Taiwan's a few decades ago. If the regulators are not given enough authority and the operators merely want to get by, Taiwan's past experiences will likely be repeated, or worse.

In order to keep all the parties who participate in nuclear power energy projects vigilant and responsible, a frequent suggestion is that all governments, including Taiwan's, should build transparency into their decision-making mechanisms, open up documents to all, and invite outsiders to scrutinise their work. An international framework for transparency in nuclear power will not only encourage collaboration and cross-national information exchange, but will also help contain potential nuclear weapons ambitions.

\section{References}

AEC (Atomic Energy Council), 2002. Brief on quality control of manufacturing reactor base level 2 to 5 of the KMNP unit one. Yonghe City: AEC, 10 June.

AEC (Atomic Energy Council), 2007. Regulatory Committee Report. Yonghe City: AEC, April.

AEC (Atomic Energy Council), 2008a. Regulatory Committee Report. Yonghe City: AEC, February.

AEC (Atomic Energy Council), 2008b. Regulatory Committee Report. Yonghe City: AEC, April.

AEC (Atomic Energy Council), 2008c. Regulatory Committee Report. Yonghe City: AEC, January. 
AEC (Atomic Energy Council), 2009. Regulatory Committee Report. Yonghe City: AEC, April.

AEC (Atomic Energy Council), 2010. Regulatory Committee Report. Yonghe City: AEC, February.

AEC (Atomic Energy Council), 2011. LMNP unit number one prefueling joint preparatory inspection with USNRC. AEC Report No. NRDLM-100-05. Yonghe City: AEC, 18 July.

AEC (Atomic Energy Council), 2012. Investigation report on misconducts in Orchid Island LLW repackaging. Atomic Energy Council Report. Yonghe City: AEC, 7 November.

AEC (Atomic Energy Council), 2013. Taiwan stress test national report. 28 May.

AEC (Atomic Energy Council), 2014. Containment strength OK. Press release, 30 April.

AEC (Atomic Energy Council), 2016. Dry storage control: Regulatory dynamics. www.aec.gov.tw/核物料管制/管制動態/核電廠放射性廢 棄物--6_48_169.html (accessed 7 September 2017).

Albright, David, and Corey Gay, 1998. Taiwan: Nuclear nightmare averted. Bulletin of the Atomic Scientists 54 (November-December): 54-60. doi.org/10.1080/00963402.1998.11456811

Burr, William, ed., 1999. New Archival Evidence on Taiwanese 'Nuclear Intentions', 1966-1976. National Security Archive Electronic Briefing Book No. 20. Washington, DC: George Washington University. nsarchive.gwu.edu/NSAEBB/NSAEBB20 (accessed 2 February 2017).

Central News Agency, 1991a. Both CSNP and KSNP tripped, China Petroleum was forced to reduce consumption. 23 April.

Central News Agency, 1991b. Rolling blackout tomorrow due to malfunction in MSNP. 25 July.

Central News Agency, 1992a. Power shortage looming for the coming summer. 15 April.

Central News Agency, 1992b. Rolling blackout in Kaohsiung this afternoon, caused by Taichung Power Plant malfunction. 4 August. 
Central News Agency, 1992c. AEC: Slightly above background radiation level found in part of Ming Shan Villa. 22 August.

Central News Agency, 1992d. AEC: Radiation level in Ming Shan Villa is high. 28 August.

Central News Agency, 1994. Legislator Lu requests an investigation on whether Taipower purposely lower electricity supply. 1 June.

Central News Agency, 1995. Legislator Hsieh accuses Taipower creating electricity shortage. 12 July.

Central News Agency, 2014. NPP4 test run expected end of 2013. 27 November.

CEPD (Council of Economic Planning and Development), 1979. Assessment report of the ten major infrastructure projects. Council of Economic Planning and Development Publication. Taipei: CEPD.

Chang, Wushou, Chang-chuan Chan, and Jungder Wang, 1997. Co-contamination in recycled steel resulting in elevated civilian radiation doses: Causes and challenges. Health Physics 73(3): 465-72. doi.org/10.1097/00004032-199709000-00004

Chen, Wei-Ting, 2015. Economic Ministry: Electricity supply will be tight in coming May. Central News Agency, 16 April.

Chiu, I-jun, Hsiu-ting Wang, and Ly-zen Liu, 2013. Orchid Island has the highest cancer death rate in Taiwan. Liberty Times, 7 June.

Chung, Yun Shuan, 2009. First time ever, application for CSNP lifetime extension submitted. Central News Agency, 20 October.

Control Yuan, 1994. AEC misled public and authorities on Ming Shan Villa incident, seriously damaging government reputation. Control Yuan Publications no. 5667.21 June.

Control Yuan, 2012. Evaluation on the electricity reserve margins set by Taiwan Power Company. Investigation Report no. 101000001. 4 January.

CTI, 2012. Embarrassing! Legislator uses photos taken three years ago. CTI Television, 26 October. 
Democratic Progressive Party Principles and Guidelines, n.d. Article 64. www.dpp.org.tw/upload/history/20160728102222_link.pdf (accessed 6 March 2017).

ENSREG (European Nuclear Safety Regulators Group), 2013. EU peer review report of the Taiwanese stress tests. 13 November.

Environmental Protection Administration, Taiwan, 2008. Analysis of environmental variations on the spent fuel interim storage project of the first nuclear power plant. Document number 0971283A.

Environmental Protection Administration, Taiwan, 2009. Analysis of environmental variations on the spent fuel interim storage project of the second nuclear power plant. Document number 0980243A.

Gi, GinLing, 1998. Additional nuclear reactors may be part of Taipower's future electricity plan. Central News Agency, 9 July.

Ho, HungRo, 2008. Adding reactors to the existing nuclear plants should be considered. Central News Agency, 5 April.

Hsu, Kuang-Jung, 2013. Comments on Taiwan stress test report by Taiwan environmental protection union. 25 September.

Huang, Chiaw-Wen, 2014. Without LMNP, lifetime extensions of existing reactors must proceed - Minister said. Central News Agency, 17 April.

Huang, Chiaw-Wen, 2015. Economic Ministry warns possible blackouts next year if go nuclear free. Central News Agency, 26 January.

Huang, Chiaw-Wen, 2016. Chair Huang denied Taipower changed its power shortage assessment under nuclear free condition. Central News Agency, 23 March.

Huang, Min-Shi, 2014. Mothball and terminating reactors construction of LMNP. Central News Agency, 27 April.

INER (Institute of Nuclear Energy Research), 2015. News (in Chinese). Press Release. www.iner.gov.tw/index.php/2015-11-17-03-2134/3400/40-核研所承接台電委託計畫, 涉及球員兼裁制.html (accessed 7 September 2017). 
Lai, Hsiaotung, 2013. Land and water conservation license not in sight, CSNP dry storage plan is put off. Liberty Times, 11 September.

LanYu BiWeekly, 1996. No docking for ElectricLight I-Taipower ship. 28 April.

Lee, Ming-Yang, 2008. Current status and challenges of Taiwan nuclear energy. Scientific American (Taiwan ed.) June: 88-9.

Lee, Tsong-You, 1984. Possible origin of radioactive steel. China Daily Evening News, 27 December.

Lee, Tsong-You, 2011. More NPP4 design alternations, Taipower executives were sent to court. China Daily News, 20 June.

Legislative Yuan, Atomic Energy Council, 1985. Meeting report of the 75th Session. 11th Meeting, 9 April.

Lin, Mon-Ruh, 2016a. Under nuclear free condition, power shortages are rare, Taipower says. Central News Agency, 18 January.

Lin, Mon-Ruh, 2016b. Warning! Low on electricity reserve. Central News Agency, 30 May.

Lin, Shaw-yu, 1984. Army has nothing to do with radioactive contaminated steel. China Daily Evening News, 27 December.

Lin, Su-Yuan, 2011. Economic Ministry: Blackouts are expected in eight years of nuclear free. Central News Agency, 25 March.

Liu Ly-Zen, 2002. Where Taiwan's nuclear waste will end up. Liberty Times, 7 July.

Lo, Ru-Lan, 2002. Legislators suggest government purchase lanyu for permanent LLW site. China Daily News, 22 November.

Now News, 2011. Taiwanese nuclear plants are as safe as Buddha sitting on platform? 15 March.

Shih, Hsiu-Chuan, 2013. Nuclear referendum on ice: KMT caucus. Taipei Times, 27 September.

Small and Medium Enterprise Administration, Ministry of Economic Affairs, n.d. Taiwan's economic development. www.moeasmea.gov.tw/ ct.asp?xItem $=72 \&$ CtNode $=263 \& m p=2($ accessed 7 September 2017). 
Taipower, n.d.a. Peak load and standby capacity rate of Taipower. data. gov.tw/node/8307 (accessed 7 February 2017).

Taipower, n.d.b. What are feedbacks to local communities after the low level nuclear waste site established. www.taipower.com.tw/content/ new_info/new_info-e47.aspx?LinkID=18 (accessed 5 March 2017).

Taipower, 2005. NPP1 interim spent fuel storage plan: Report of environmental changes and countermeasures: Environmental Impact Assessment No. 0960067020.

Taiwan Power Company, n.d. Household electricity consumption guide. www.taipower.com.tw/content/new_info/new_info_in.aspx? LinkID=27 (accessed 2 February 2017).

Tang, Jian Ling, 2014. AEC: U-turn for not extending reactor lifetime policy. Liberty Times, 4 November.

Tang Jia-lin, and Yi-lo Chien, 2014. NPP4 containment leaks. Liberty Times, 12 May.

Tsai Chuen-horng, 2013. Atomic Energy Council special report on overall geological survey of operating NPPs and the fourth NPP to the economic committee, Legislative Yuan. Report to the Economic Committee, Legislative Yuan, 17 April.

Tung Sen News, 2011. Worry about radiation? AEC: Koreans do not worry even though they are closer. 14 March.

United Daily News, 1976. Executive Yuan solemnly declares no intention to develop nuclear weapon. 17 September.

Wang, Fong, 2010. Israeli nuclear expert secretly assisted Chiang Kai-Shek developing nuclear weapon. Yazhou zhoukan [Asia Weekly], 18 April.

Wang, To-Far, 1991. Does LMNP have to be built? China Times, 7 January.

Wang, To-Far, 2015. The curious illness of power shortage. Taiwan People News, 6 June.

Wang, Yu-Lin, 1996. Radioactive Formosa: Unearth the radioactive waste scandals. Radiation Safety Improvement Organisation. 
Wang, Yu-Su, and Bin Wei, 2008. NPP4 hidden dangers: Taipower altered nuclear power plant design without permission. Apple Daily News, 8 February.

Wei, Su, 2005. Nuclear power plant lifetime extension, Atomic Energy Council will thoroughly check its safety. Central News Agency, 10 January.

Weiner, Tim, 2007. Legacy of Ashes: History of the CIA. New York: Doubleday.

Yen, Zo-jin, Hsiao-Kuang Shih, Wen-Hua Hsieh, Jia-Chi Lin, and JiHsien Fang, 2011. Radioactive dusts make turns? Scholars question AEC instrument sensitivity. Liberty Times, 31 March. 
This text is taken from Learning from Fukushima: Nuclear power in East Asia, edited by Peter Van Ness and Mel Gurtov, published 2017 by ANU Press, The Australian National University, Canberra, Australia.

dx.doi.org/10.22459/LF.09.2017.06 